\title{
Innovativeness of SMEs in Small Non-Oil Producing Post- Communist Economies
}

\author{
Asst. Prof. Dr. Kamalbek Karymshakov (Kyrgyzstan-Turkey Manas University, Kyrgyzstan) \\ Dr. Burulcha Sulaimanova (Kyrgyzstan-Turkey Manas University, Kyrgyzstan) \\ Dr. Dastan Aseinov (Kyrgyzstan-Turkey Manas University, Kyrgyzstan)
}

\begin{abstract}
This paper aims to study the determinants of innovation propensity of small and medium-sized enterprises (SMEs) in five small non-oil exporting Former Soviet Union countries. Empirical analysis is based on the data from the fifth wave of the Business Environment and Enterprise Performance Survey (BEEPS). Innovation of SMEs is measured by five innovation practices: innovation in goods services, process, organization, marketing and R\&D spending. For each aspect of innovation bivariate regression analysis is applied. Estimation results shows that experience of managers has curvilinear effect on the innovation in SMEs. Foreign participation, export orientation and competitiveness in sectors are important for innovation.
\end{abstract}

\section{Introduction}

Small and medium-sized enterprises promote economic growth through creation of new jobs and development of innovative products (Scase, 1997; Skuras et al., 2008; Ionica, 2013). Compared to large firms SMEs may quickly adapt to new socio-economic environment and find out new ways of activity (McIntyre, 2001:11; Rogers, 2004:143, Love \& Roper, 2015:29). Recent economic transition of the former Soviet Union (FSU) countries to market economy and making of the entrepreneurship in these challenging environment have made SMEs even more important for these economies (Aidis, 2003).

The long-term sustainable economic development requires innovation activities of enterprises. SMEs and individual enterprises may demonstrate more dynamic tendency towards introduction of innovation (Love \& Roper, 2015). Innovativeness of these firms may depend on different factors ranging from the characteristics of firms' leaders to the access of financial resources.

Empirical literature determines different factors for innovation of SMEs. Among them financial constraints are found as one of the important elements of government support to increase innovation activity (Landesmann et al., 2016; Skuras et al., 2008). Some studies assert that along with this non-financial support to increase productivity of the labour force is also crucial (Szczepanska-Woszczyna, 2014). On this point study by Norek \& Arenhardt (2015) on Brazilian and Polish SMEs indicates that lack of qualified labour together with financial constraints as major difficulties related with innovation.

Other characteristics of firms which are significant for the innovation propensity of SMEs are size and technological capacity of firms. Findings by Bayarçelik et. al. (2014) on Turkish case indicate that among other factors size of firm have significant impact over the innovativeness of SMEs. Some of the studies point out importance of the external environmental conditions too. Thus, De Mel et al. (2009) investigating determinants of innovation in micro, small, and medium enterprises in Sri Lanka, demonstrate that firm size has positive impact on the process and organizational innovations, while less on product innovations. Along with this pressure coming from the competition in the industry negatively affects these innovation aspects. However, SzczepanskaWoszczyna (2014) found positive influence of the constant pressure coming from the competitors over the innovation in Polish SMEs. Manager characteristics such as gender, experience and entrepreneur skills, are also important for the innovation propensity of firms too (Romijn \& Albaladejo, 2002; Norek \& Costa, 2015; Akulava, 2015).

However, not only internal firm level characteristics, but also external cooperation is found to be important for innovation of SMEs. Turriago-Hoyos et al. (2015) in case of the Colombian SMEs argue that firm size and cooperation with other stakeholders, such as research institutions and foreign industrial groups, have more influence on production innovation. Podmetina (2011) emphasizes that innovation implementation through internationalization and cooperation with external partners can provide for Russian SMEs with opportunities to enter into new markets. Analogically, Ionica (2013) concludes that innovation in SMEs of Romania have been influenced by international strategic partnerships. In a similar vein, studies by Ehrenberger et.al. (2015) on Czech Republic, Radas \& Božić (2009) on Croatia, Pikkemaat (2008) on Austria, Keizer et al. (2002) on Netherlands confirm the positive influence of external cooperation on innovation of SMEs.

Although there are large number of studies on the innovation and SMEs, empirical evidence on the post-soviet countries is limited. Although, FSU countries have some common historical background for the enterprise development, difference in size of the economies, abundance of the natural resources and government policies have been expressed in diverging outcomes of economic performance (Iradian, 2007). Moreover, at the aftermath 
of the comprehensive economic reforms perception of government on the priority of SMEs in economic development varied (Smallbone \& Welter, 2001).

This study aims to investigate the factors that determine innovation of SMEs in small non-oil exporting FSU countries: Armenia, Georgia, Kyrgyzstan, Moldova and Tajikistan.

Under the conditions of comparatively smaller economies without large oil resources increase importance of SMEs for economic development. We use the data from the 5th wave of the Business Environment and Enterprise Performance Survey (BEEPS) and measure innovation with five innovation practices, which are indicated by the binary response variables. For each innovation activities, bivariate regression analysis is applied.

This paper is structured as follows. Next section explains methodology. Section 3 entails data description and briefly discusses descriptive statistics. Section 4 presents estimation results. Section 5 concludes.

\section{Methodology}

For the purpose of examining factors affecting innovation activity of SMEs we use binary response, probit models, for estimations. The innovation of firms is measured within five categories: innovation in goods services, process, organization, marketing and R\&D spending. Each innovation category has binary response character. Formally, model is given below (Wooldridge, 2002):

$$
\begin{gathered}
P\left(y_{i}=1 \mid x_{i}\right)=G\left(\beta_{0}+\beta_{1} x_{1}+\cdots+\beta_{k} x_{k}\right)=G\left(\beta_{0}+x \beta\right) \\
G(z)=\Phi(z) \equiv \int_{-\infty}^{z} \phi(v) d v \\
\phi(z)=(2 \pi)^{-1 / 2} \exp \left(-z^{2} / 2\right)
\end{gathered}
$$

where $\mathrm{G}$ is the standard normal cumulative distribution function (cdf) and $\phi(z)$ indicates standard normal density. $y_{i}$ is the discrete dependent variable, taking values of zero or one, showing the innovativeness of the firm; $x_{i}$ is the set of explanatory variables.

Covariates used in the analysis follow empirical literature and cover both managerial and firm characteristics, including some aspects of the external environment. For detailed variable description see Table A.1. in Appendix. Managerial features are measured by the gender and experience variables. In particular, relationship between experience and innovation may not only be linear, but also may have curvilinear path. At the earlier stages of the managerial experience SMEs may be more active in adapting new approach for production, organizational structure and other aspects of innovation. However, with longer managerial experience owners or managers of SMEs may take passive innovative position because of the several reasons: higher personal age and less desire to work on innovative approach or belonging to the "old cohort" of managers that may find difficult adaptation to new conditions through competitive and technological changes. The recent short history of emerging private sector and entrepreneurships in post-communist economies the latter argument may have higher validity in our analysis. Following this potential curvilinear effect square of experience is included too.

Firm characteristics include years since establishment, dummy variables on ownership structure and foreign participation. Industry type variable is included through four sectors: foods manufacturing, construction, retail services and other industry. Other variables indicate reported competition level in the industry, whether firm exports, has provided trainings and has current credit loan.

\section{Data and Descriptive Statistics}

This study is based on the data of the fifth wave of the Business Environment and Enterprise Performance Survey (BEEPS) for five countries: Armenia, Georgia, Kyrgyzstan, Moldova and Tajikistan. Total sample consists of 1081 micro, small and medium-sized enterprises. Following the dataset micro is defined as firms having less than 5 employees, small between 5 and 19, and medium between 20 and 99. Data includes wide range of data on firm activities such as production, expectations, regulatory burden, and different section of the questionnaire is focused on innovation activities.

Innovation activity of enterprises is measured by five aspects: introduction of new products or services innovation in goods and services; introduction of new methods of production of goods and services - innovation in process; introduction of new or significant improvement in organizational or management practices - innovation in organization; introduction of new marketing methods - marketing innovation; and whether firm did spending on research and development. These are dummy variables, indicating whether firms performed these activities or not.

Table 1. present share of firms indicated each innovation activity by countries in the sample. Among five countries the most innovative SMEs are in Kyrgyzstan and Moldova. In average and relative terms SMEs in Georgia reported lower level of innovation in all five aspects. At the total sample about 20 per cent of SMEs are 
engaged into innovation activities. However, SMEs show different performance depending on the types of innovation. The least intensive type of innovation is $R \& D$, while other types receive substantially larger consideration of firms. For instance, in Kyrgyzstan more than 30 per cent of SMEs indicated innovation in goods and services, organization and marketing, while Armenia and Georgia innovation in goods and services has comparatively larger share. These varying intensities of innovation activities may be related with their cost and priority for SMEs. Financing R\&D activities may be costly given their uncertain results and small size of firms. On the other hand, competitive environment in the industry may pressure SMEs to focus on other issues, such as better promotion of products or improvement of managerial practices of firms.

\begin{tabular}{|c|c|c|c|c|c|}
\hline & $\begin{array}{c}\text { Innovation in goods } \\
\text { and services }\end{array}$ & $\begin{array}{c}\text { Innovation in } \\
\text { process }\end{array}$ & $\begin{array}{c}\text { Innovation in } \\
\text { organization }\end{array}$ & $\begin{array}{c}\text { Innovation in } \\
\text { marketing }\end{array}$ & R\&D \\
\hline Armenia & 11.60 & 4.97 & 4.42 & 9.94 & 2.76 \\
\hline Georgia & 8.84 & 7.23 & 3.21 & 5.62 & 2.01 \\
\hline Kyrgyz Rep. & 36.87 & 22.73 & 36.36 & 39.90 & 8.59 \\
\hline Moldova & 31.29 & 30.67 & 25.77 & 25.77 & 7.98 \\
\hline Tajikistan & 13.45 & 9.66 & 19.31 & 26.90 & 5.52 \\
\hline Total & 19.06 & 13.88 & 17.21 & 21.37 & 5.18 \\
\hline
\end{tabular}

Table 1. Innovation Activity of Enterprises (in \%, by Country) Source:5th Business Environment and Enterprise Performance Survey (BEEPS)

Review of the empirical literature shows that innovation activities depends on different firm and managerial characteristics. Table 2. describes the main indicators of SMEs, which are taken into analysis. In general, SMEs are represented by male headed companies, which are more experienced than women CEO. The firm statistics show that most firms have short history since establishment and counts around 11 years, which probably could be explained by the disintegration of Soviet Union and later development of private sector in these economies.

The distribution of legal statuses of SMEs shows that almost 92 per cent of firms are shareholding companies, which do not trade their shares in the stock market, while only half percent of shareholding companies trade their shares openly. Around 7 per cent of firms have sole proprietorship. About 8 per cent of firms have foreign participation. Large share of SMEs are in sectors of service - almost 64 per cent, while activities of less than 34 per cent are in manufacturing. Services sector has low capital intensity that makes it more attractive for the establishment of SMEs without substantial financial costs. Most of the firms functioning in the service industries, and women headed firms more likely (77 per cent) to be in this sector, and only 23 per cent in the manufacturing industries. Interestingly $60 \%$ of women headed firms located in the capital city, indicating that women are more likely to manage firms in the urban areas. 28 per cent of firms conduct training activities to their employees, which can be related with some types of innovation activities of SMEs. Another interesting feature of SMEs in these countries is that more than 30 per cent of firms' report facing competition against unregistered firms. This information indicates the extent to which informal economic activities are spread and may create competition pressure for formal firms.

\begin{tabular}{|c|c|c|}
\hline & Obs. & $\%$ \\
\hline Firm amount & 1081 & 100 \\
\hline Experience of the manager (years, mean) & - & 13.56 \\
\hline Years since establishment (mean) & - & 11.25 \\
\hline \multicolumn{3}{|l|}{ Firm structure } \\
\hline -Shareholding company with shares traded in the stock market & 4 & 0.37 \\
\hline -Shareholding company with non-traded shares or shares traded privately & 990 & 91.58 \\
\hline -Sole proprietorship & 62 & 5.74 \\
\hline - Partnership and limited partnership & 10 & 0.93 \\
\hline -Other legal status & 15 & 1.39 \\
\hline Foreign participation & 89 & 8.23 \\
\hline \multicolumn{3}{|l|}{ Industry type: } \\
\hline -Manufacturing & 362 & 33.49 \\
\hline -Service & 719 & 66.51 \\
\hline Location in capital city & 494 & 45.70 \\
\hline Exporter firm & 117 & 10.82 \\
\hline Training activities & 302 & 27.94 \\
\hline Competition against unregistered firms & 356 & 32.93 \\
\hline Credit or loan from financial institutions & 315 & 29.33 \\
\hline
\end{tabular}

Table 2. Descriptive Statistics Source: 5th Business Environment and Enterprise Performance Survey (BEEPS)

\section{Estimation Results}

Table 3. reports marginal effects from estimation of probit model for each innovation component. Most of the variables have expected sign. Findings show that there is no relationship between gender of CEO and 
innovativeness of the enterprise. However, interesting results are indicated in case of the impact of experience of CEOs on innovation. In order to examine the potential curvilinear relationship between experience of managers and innovation variable measuring the experience in years and their square values is included as distinct variable. Findings show that there is statistically significant and positive relation exists between experience of manager of firm and its innovation indicators. However, squared value of the CEO experience shows statistically significant negative effect on innovation, meaning that CEOs with increase in experience after some threshold values less likely to introduce innovation in firms. Although marginal effect of the negative impact of longer experience is considerably lower.

Curvilinear effect of experience of managers has some support from the establishment history of SMEs too. As the experience of CEO, the establishment history of firm shows the same pattern, the propensity to invest in innovation increases with increase in years since establishment, then after definite years it reduces. If to consider that SMEs are mostly represented by companies with non-traded shares, then the probability of staying same managers on for the longer time is high. Therefore, curvilinear effect of both experience and establishment history is expected outcome. Shareholding companies that trade their shares in stock market more likely to introduce new goods, services, implement new production process and introduce a new marketing strategy.

Empirical findings show that foreign participation in the firm positively influences innovation in firms, thus these firms more likely to introduce new goods, marketing strategies and organizational management rather than firms that don't have foreign participation in the ownership structure. Interesting results are indicated by the sector of activity. SMEs working in the food manufacturing industries have innovation works in goods and services and process, while firm in construction have negative propensity to innovate in all types of innovation compared to other industries reference group. Retails services sector demonstrate statistically significant negative innovation in process only.

\begin{tabular}{|c|c|c|c|c|c|}
\hline & \multicolumn{5}{|c|}{ Innovation in } \\
\hline & Goods/Services & Process & Organization & Marketing & R\&D \\
\hline \multicolumn{6}{|l|}{ CEO characteristics: } \\
\hline Gender(female $=1)$ & 0.0092 & 0.0394 & 0.0317 & -0.0144 & 0.0044 \\
\hline Experience & $0.0066 * *$ & $0.0087 * * *$ & $0.1038 * * *$ & $0.0116^{* * *}$ & $0.0033 *$ \\
\hline Squared experience & $-0.0001 * *$ & $-0.0001 * *$ & $-0.0002 * * *$ & $-0.0003 * * *$ & $-0.00007 *$ \\
\hline \multicolumn{6}{|l|}{ Firm characteristics: } \\
\hline Years since establishment & $0.0069 * *$ & $0.0056^{* *}$ & $0.0120 * * *$ & $0.0074 *$ & 0.0015 \\
\hline Squared years since establishment & -0.00008 & $-0.00007 *$ & $-0.0002 * *$ & $-0.0001 *$ & -0.00001 \\
\hline \multicolumn{6}{|c|}{ Firm structure (reference group: Other legal status) } \\
\hline - $\quad$ Shares traded & $0.7409 * * *$ & $0.5167 * *$ & 0.3910 & $0.5267 * *$ & 0.4040 \\
\hline - $\quad$ Non-traded shares & $0.0897 * * *$ & 0.0395 & 0.0382 & $0.1219 * * *$ & $0.0275 * * *$ \\
\hline Foreign participant & $0.0877^{*}$ & 0.0063 & $0.1264 * *$ & $0.1381 * *$ & $0.0448 *$ \\
\hline \multicolumn{6}{|c|}{ Industry type (reference group: other industries) } \\
\hline - $\quad$ Food manufacturing & $0.1541 * * *$ & $0.1368 * * *$ & 0.0404 & 0.0696 & 0.0165 \\
\hline - $\quad$ Construction services & $-0.0731 * *$ & $-0.0571 * *$ & $-0.0684 * *$ & $-0.0795 * *$ & $-0.026 * * *$ \\
\hline - $\quad$ Retail services & -0.0103 & $-0.0666 * * *$ & 0.0107 & 0.0373 & -0.0082 \\
\hline Location & $0.0556^{* *}$ & -0.0264 & 0.0047 & 0.0286 & -0.0054 \\
\hline Exporter firm & $0.1112^{* *}$ & 0.0259 & 0.0608 & $0.1189^{* *}$ & $0.0370^{*}$ \\
\hline Training & $0.1794 * * *$ & $0.1104 * * *$ & $0.2250 * * *$ & $0.2288^{* * *}$ & $0.0590 * * *$ \\
\hline Competition & $0.0510 * *$ & $0.0514^{* *}$ & 0.0316 & 0.0428 & 0.0180 \\
\hline Credit & 0.0130 & $0.0400 *$ & $-0.0407 *$ & -0.0121 & -0.0037 \\
\hline
\end{tabular}

Table 3. Estimation Results for Probit Models (Marginal Effect Estimates)

These findings suggest that innovativeness of SMEs in particular sectors of the economy does not have actively growing tendency. Especially the negative sign of innovation in results may suggest that SMEs may grow or maintain their current position by growing demand for their products. But low level of competition in these sectors and low exporting capacity of SMEs do not create incentives to look for innovation opportunities. These arguments are supported by the exporter and competition variables in the model. Both of them have positive impact over few innovation types.

Location of firms significantly impacts only on innovation of new products. SMEs located in the capital city may have larger consumer market and lower costs for logistics that may induce them to focus on the attempt to introduce new products and services. Moreover, being located may represent another advantage of accessing current knowledge on technology and innovation opportunities. Training of permanent employees positively correlated with all types of innovation. This result points out the fact that most of the innovation activities are associated with different forms of training activities. However, their magnitude may differ by innovation types. For instance, in our result R\&D activities have lower marginal effect of training compared to other innovation elements. 
Availability of financial resources is considered as one of the important constraints for innovation of firms. Estimation results show that it has some impact at less statistically significance level over the new production process and organizational management. Nevertheless, these findings do not provide with enough evidence to conclude about significant impact of credits from financial institutions over the innovation of firms. This fact may have two explanations. First, financial system in these countries are not developed and do not supply enough financial resources for innovation activities. Second, SMEs using loans from financial institutions use them for other activities and not necessarily for innovative works.

General assessment of estimation results by types of innovation indicates that among five measured innovation activities R\&D remains as affected only by a few variables in the model, while innovation in goods and services are most intensive among SMEs. These findings suggest that R\&D activities are limited in SMEs of these economies.

\section{Conclusions}

This study using the data from the Business Environment and Enterprise Performance Survey (BEEPS) examined factors affecting innovation activities of SMEs in five small post-communist economies: Armenia, Georgia, Kyrgyzstan, Moldova and Tajikistan. The broad definition of innovation is focused on and measured by dummy variables in five aspects: introduction of new products or services; introduction of new methods of production of goods and services; introduction of new or significant improvement in organizational or management practices; introduction of new marketing methods; and whether firm did spend on research and development. Because of the binary response character innovation variables, probit model is estimated with explanatory variables on manager and firm characteristics.

In general, estimation results indicate the low intensity of R\&D in innovativeness of SMEs, while innovation in goods and services is more widespread. One of the interesting results is that curvilinear impact of experience of SMEs managers and innovative activities exist. This finding may indicate about different nature of entrepreneurship of the first and next generations. Moreover, given the recent short history of emerging private sector in post-communist economies managers with longer experience may represent the "old cohort" of entrepreneurs and may be reluctant to innovation. However, our study does not research making entrepreneurship and generational difference of managers in the in post-communist economies context. Therefore, further studies for understanding this relationship may provide with more detailed insights of this relationship.

Another interesting result is that innovation propensity of SMEs may have different pattern by sectors of the economy and depending on the foreign participation. Growing demand in some sectors may drive growth of the enterprises, but that factor may not be enough for inducing firms for the innovation. However, in perspectives growing competitive environment, foreign participation and export oriented activities of SMEs may create conditions for their higher propensity to innovate. Our results do not provide with enough evidence on the fundamental role of financial resources for innovativeness of firms. However, different study focusing on this particular topic is needed.

These findings have several policy implications. Following these results, it can be suggested that government policy towards increasing competitive environment and openness of economies are fundamental for innovation of firms. Competition forces firms to innovate in order to survive, while openness of the economy provides with exporting opportunities and participation of the foreign capital in ownership structure of firms. Especially the latter factor may significantly reduce costs of innovation through more rapid technological transformation from abroad. Concentration of the most SMEs in capital city shows that more active government support of SMEs in other regions of a country, would lead more balanced intraregional development of these economies, which in the long run is conducive to the sustainable economic development.

\section{References}

- $\quad$ Aidis, 2003. "Officially despised yet tolerated: open-air markets and entrepreneurship in post-socialist countries", Post-Communist Economies, 15(3), pp.461-473.

- Akulava, 2015. “Gender and Innovativeness of the Enterprise: the Case of Transition”, Belarusian Economic Research and Outreach Center (BEROC), No. 31

- De Mel, McKenzie, \& Woodruff, 2009. "Innovative firms or innovative owners? Determinants of innovation in micro, small, and medium enterprises. Determinants of Innovation in Micro, Small, and Medium Enterprises", World Bank Policy Research Working Paper Series

- Ehrenberger, Koudelkova, \& Strielkowski, 2015. "Factors influencing innovation in small and medium enterprises in the Czech Republic", Periodica Polytechnica, Social and Management Sciences, 23(2), p.73.

- Ionica, 2013. "The Impact of Innovation in Romanian Small and Medium-Sized Enterprises on Economic Growth Development”, Journal of Knowledge Management, Economics and Information Technology, 3(6), pp. 409-422 
- Iradian, 2007., "Rapid Growth in Transition Economies: Panel Regression Approach", IMF Working Paper, No 07/170

- Landesmann, Leitner, \& Stehrer, 2016. “Changing Patterns in M\&E-Investment-Based Innovation Strategies in CESEE and FSU Countries”, Working Paper, The Vienna Institute for International Economic Studies, No. 123

- $\quad$ Love, \& Roper, 2015. "SME innovation, exporting and growth: A review of existing evidence", International Small Business Journal, 33(1), p. 28-48.

- McIntyre, 2001. "The role of small and medium enterprises in transition: Growth and entrepreneurship", UNU World Institute for Development Economics Research (UNU/WIDER).

- Norek, \& Arenhardt, 2015. "Comparative Analysis of Innovative Activity Determinants in Selected SME's in Brazil and Poland. Results of Empirical Researches", Equilibrium. Quarterly Journal of Economics and Economic Policy, 10(2), pp.157-181.

- Norek, \& Costa, (2015). "Evaluation of the impact of the innovative potential of the companies from the SMEs sector on the efficiency of innovative actions. Suggestion of the evaluation method", International Journal of Management Science \& Technology Information, (16).

- Pikkemaat, 2008. "Innovation in small and medium-sized tourism enterprises in Tyrol, Austria", The International Journal of Entrepreneurship and Innovation, 9(3), pp.187-197.

- Podmetina, 2011. "Innovation and Internationalisation in Russian Companies: Challenges and Opportunities for Open Innovation and Cooperation", Doctoral Dissertation, Lappeenranta University of Technology.

- Radas, \& Božić, 2009. "The antecedents of SME innovativeness in an emerging transition economy”, Technovation, 29(6), pp.438-450.

- Rogers, 2004. "Networks, firm size and innovation”, Small business economics, 22(2), pp.141-153.

- Romijn, \& Albaladejo, 2002. "Determinants of innovation capability in small electronics and software firms in southeast England", Research Policy, 31(7), pp.1053-1067.

- Scase, 1997. "The role of small businesses in the economic transformation of Eastern Europe: real but relatively unimportant?”, International Small Business Journal, 16(1), pp.13-21.

- Skuras, Tsegenidi, \& Tsekouras, 2008. "Product innovation and the decision to invest in fixed capital assets: Evidence from an SME survey in six European Union member states”, Research Policy, 37(10), pp.17781789.

- Smallbone, \& Welter, 2001. "The role of government in SME development in transition economies", International Small Business Journal, 19(4), pp.63-77.

- Szczepanska-Woszczyna, K., 2014. "Determinants of Innovation Activities in Small and Medium-Sized Enterprises in Poland", Journal of Advanced Research in Management (JARM), (2 (10)), pp.65-73.

- Turriago-Hoyos, Thoene, Bernal-Torres, and Alfonso-Lizarazo, 2015. Product Innovation, Research and Development and Technology Acquisition: A Case Study of the Industrial Sector in Colombia. Institutions and Economies, 7(2).

- Wooldridge, 2002. Econometric analysis of cross section and panel data //Cambridge, MA: MIT Press. 2002. 


\section{Appendix}

\begin{tabular}{|c|c|c|}
\hline \multicolumn{3}{|r|}{ Dependent variables: } \\
\hline \multicolumn{2}{|c|}{ Innovation in goods services } & $1=$ if firm has introduced new products or services \\
\hline \multicolumn{2}{|c|}{ Innovation in process } & $1=$ if firm has introduced new methods of production of goods and services \\
\hline \multicolumn{2}{|c|}{ Innovation in organization } & $1=$ if firm has introduced or improved organizational practices \\
\hline \multicolumn{2}{|c|}{ Innovation in marketing } & $1=$ if firm has introduced new marketing methods \\
\hline \multirow{2}{*}{\multicolumn{2}{|c|}{ Innovation in activity }} & $1=$ if firm has has spend on research and development \\
\hline & & Explanatory variables: \\
\hline \multicolumn{3}{|c|}{ CEO characteristics: } \\
\hline \multicolumn{2}{|l|}{ Gender } & $1=\mathrm{CEO}$ is female $; 0=\mathrm{CEO}$ is male \\
\hline \multicolumn{2}{|c|}{ Experience } & The years of experience of CEO (age-education years) \\
\hline \multicolumn{2}{|c|}{ Squared experience } & Squared years of experience of CEO \\
\hline \multicolumn{3}{|c|}{ Firm characteristics: } \\
\hline \multicolumn{2}{|c|}{ Years since establishment } & Years since establishment of the firm (2013-establishment year) \\
\hline \multicolumn{2}{|c|}{ Squared years since establishment } & Squared years since establishment \\
\hline \multicolumn{3}{|c|}{ Firm structure: } \\
\hline- & Shares traded & $1=$ Shareholding company with shares traded in the stock market \\
\hline- & Non-traded shares & $1=$ Shareholding company with non-traded shares or shares traded privately \\
\hline- & Other legal status & $1=$ Sole proprietorship, partnership, limited partnership or other legal status \\
\hline \multicolumn{2}{|c|}{ Foreign participation } & $1=$ firm has private foreign individuals or companies as owner \\
\hline \multicolumn{3}{|c|}{ Industry type } \\
\hline- & Food manufacturing & $1=$ firm is in food manufacturing sector \\
\hline- & Construction services & $1=$ firm is in construction sector \\
\hline- & Retail services & $1=$ firm is in retail services sector \\
\hline- & Other industry & $1=$ firm is in other industry sectors \\
\hline \multicolumn{2}{|c|}{ Location } & $1=$ firm is located in capital city \\
\hline \multicolumn{2}{|c|}{ Exporter firm } & $1=$ firm is exporting its products \\
\hline \multicolumn{2}{|c|}{ Training } & $1=$ firm makes formal training program for permanent employees \\
\hline \multicolumn{2}{|c|}{ Competition } & $1=$ firm competes with unregistered firms \\
\hline \multicolumn{2}{|l|}{ Credit } & $1=$ firm currently has a line of credit from a financial institution \\
\hline
\end{tabular}

Table A. 1. Explanation of Variables 


\begin{tabular}{|c|c|c|c|c|c|}
\hline & \multicolumn{5}{|c|}{ Innovation in } \\
\hline & Goods/Services & Process & Organization & Marketing & Activity \\
\hline \multicolumn{6}{|l|}{ CEO characteristics: } \\
\hline Gender(female $=1)$ & $\begin{array}{c}0.0370 \\
(0.1176)\end{array}$ & $\begin{array}{c}0.1932 \\
(0.1250)\end{array}$ & $\begin{array}{c}0.1410 \\
(0.1207)\end{array}$ & $\begin{array}{c}-0.0557 \\
(0.1164)\end{array}$ & $\begin{array}{c}0.0633 \\
(0.1787)\end{array}$ \\
\hline Experience & $\begin{array}{c}0.0268 * * \\
(0.0132)\end{array}$ & $\begin{array}{c}0.0453 * * \\
(0.0165)\end{array}$ & $\begin{array}{c}0.0483 * * \\
(0.0164)\end{array}$ & $\begin{array}{c}0.0439 * * \\
(0.0141)\end{array}$ & $\begin{array}{l}0.0493^{*} \\
(0.0268)\end{array}$ \\
\hline Experience $^{2}$ & $\begin{array}{c}-0.0007 * * \\
(0.0003)\end{array}$ & $\begin{array}{c}-0.0010^{* *} \\
(0.0004)\end{array}$ & $\begin{array}{c}-0.0012 * * \\
(0.0004)\end{array}$ & $\begin{array}{c}-0.0011 * * \\
(0.0004)\end{array}$ & $\begin{array}{l}-0.0011 * \\
(0.0007)\end{array}$ \\
\hline \multicolumn{6}{|l|}{ Firm characteristics: } \\
\hline Years since establishment & $\begin{array}{c}0.0268^{* *} \\
(0.0119)\end{array}$ & $\begin{array}{c}0.0278 * * \\
(0.0126)\end{array}$ & $\begin{array}{c}0.0524 * * * \\
(0.0150)\end{array}$ & $\begin{array}{l}0.0254 * \\
(0.0141)\end{array}$ & $\begin{array}{c}0.0214 \\
(0.0189)\end{array}$ \\
\hline Years since establishment $^{2}$ & $\begin{array}{l}-0.0003 \\
(0.0002)\end{array}$ & $\begin{array}{l}-0.0004 * \\
(0.0002)\end{array}$ & $\begin{array}{c}-0.0008^{* *} \\
(0.0004)\end{array}$ & $\begin{array}{l}-0.0005^{*} \\
(0.0004)\end{array}$ & $\begin{array}{l}-0.0002 \\
(0.0004)\end{array}$ \\
\hline \multicolumn{6}{|c|}{ Firm structure (reference group: Other legal status ) } \\
\hline Shares traded & $\begin{array}{c}2.2810^{* *} \\
(0.7744)\end{array}$ & $\begin{array}{l}1.5464 * * \\
(0.6540)\end{array}$ & $\begin{array}{c}1.1745 \\
(0.7498)\end{array}$ & $\begin{array}{l}1.4588 * * \\
(0.7166)\end{array}$ & $\begin{array}{c}1.7274 * * \\
(0.8395)\end{array}$ \\
\hline - $\quad$ Non-traded shares & $\begin{array}{c}0.4455^{* *} \\
(0.2139)\end{array}$ & $\begin{array}{c}0.2340 \\
(0.2066)\end{array}$ & $\begin{array}{c}0.1958 \\
(0.2073)\end{array}$ & $\begin{array}{c}0.5944 * * \\
(0.2192)\end{array}$ & $\begin{array}{c}0.6853 \\
(0.4319)\end{array}$ \\
\hline Foreign participation & $\begin{array}{l}0.3166^{* *} \\
(0.1608)\end{array}$ & $\begin{array}{c}0.0324 \\
(0.1835)\end{array}$ & $\begin{array}{l}0.4802 * * \\
(0.1651)\end{array}$ & $\begin{array}{l}0.4503 * * \\
(0.1589)\end{array}$ & $\begin{array}{c}0.4645^{* *} \\
(0.2009)\end{array}$ \\
\hline \multicolumn{6}{|c|}{ Industry type (reference group: other industries) } \\
\hline Food manufacturing & $\begin{array}{c}0.5248 * * * \\
(0.1519)\end{array}$ & $\begin{array}{c}0.5606^{* * *} \\
(0.1528)\end{array}$ & $\begin{array}{c}0.1744 \\
(0.1711)\end{array}$ & $\begin{array}{c}0.2429 \\
(0.1569)\end{array}$ & $\begin{array}{c}0.2102 \\
(0.2249)\end{array}$ \\
\hline Construction services & $\begin{array}{c}-0.3437^{*} \\
(0.1855)\end{array}$ & $\begin{array}{l}-0.3572 * \\
(0.1947)\end{array}$ & $\begin{array}{l}-0.3787^{*} \\
(0.1948)\end{array}$ & $\begin{array}{l}-0.3446^{*} \\
(0.1782)\end{array}$ & $\begin{array}{l}-0.5959^{*} \\
(0.3434)\end{array}$ \\
\hline - $\quad$ Retail services & $\begin{array}{l}-0.0430 \\
(0.1099)\end{array}$ & $\begin{array}{c}-0.3786^{* *} \\
(0.1264)\end{array}$ & $\begin{array}{c}0.0495 \\
(0.1135)\end{array}$ & $\begin{array}{c}0.1381 \\
(0.1064)\end{array}$ & $\begin{array}{l}-0.1285 \\
(0.1687)\end{array}$ \\
\hline Location & $\begin{array}{l}0.2243 * * \\
(0.0987)\end{array}$ & $\begin{array}{l}-0.1402 \\
(0.1081)\end{array}$ & $\begin{array}{c}0.0218 \\
(0.1038)\end{array}$ & $\begin{array}{c}0.1076 \\
(0.0962)\end{array}$ & $\begin{array}{l}-0.0816 \\
(0.1499)\end{array}$ \\
\hline Exporter firm & $\begin{array}{c}0.3942 * * \\
(0.1372)\end{array}$ & $\begin{array}{c}0.1280 \\
(0.1543)\end{array}$ & $\begin{array}{l}0.2542^{*} \\
(0.1477)\end{array}$ & $\begin{array}{l}0.3968 * * \\
(0.1396)\end{array}$ & $\begin{array}{c}0.4085^{* *} \\
(0.1842)\end{array}$ \\
\hline Training & $\begin{array}{c}0.6447 * * * \\
(0.1008)\end{array}$ & $\begin{array}{c}0.5066 * * * \\
(0.1097)\end{array}$ & $\begin{array}{c}0.8661 * * * \\
(0.1029)\end{array}$ & $\begin{array}{c}0.7631 * * * \\
(0.0980)\end{array}$ & $\begin{array}{l}0.6541 * * * \\
(0.1465)\end{array}$ \\
\hline Competition & $\begin{array}{c}0.2011 * * \\
(0.0987)\end{array}$ & $\begin{array}{c}0.2553 * * \\
(0.1056)\end{array}$ & $\begin{array}{c}0.1433 \\
(0.1034)\end{array}$ & $\begin{array}{c}0.1583 \\
(0.0973)\end{array}$ & $\begin{array}{l}0.2472 * \\
(0.1453)\end{array}$ \\
\hline Credit & $\begin{array}{c}0.0523 \\
(0.1032)\end{array}$ & $\begin{array}{l}0.1991 * \\
(0.1089)\end{array}$ & $\begin{array}{l}-0.1986^{*} \\
(0.1118)\end{array}$ & $\begin{array}{l}-0.0466 \\
(0.1021)\end{array}$ & $\begin{array}{l}-0.0570 \\
(0.1570)\end{array}$ \\
\hline Constant & $\begin{array}{c}-2.204 * * * \\
(0.2498) \\
\end{array}$ & $\begin{array}{c}-2.135 * * * \\
(0.2532) \\
\end{array}$ & $\begin{array}{c}-2.2754 * * * \\
(0.2562)\end{array}$ & $\begin{array}{c}-2.283 * * * \\
(0.2564) \\
\end{array}$ & $\begin{array}{l}-3.25 * * * \\
(0.5041) \\
\end{array}$ \\
\hline Observation & 1074 & 1074 & 1074 & 1074 & 1074 \\
\hline LR chi2 & $127.99 * * *$ & $101.97 * * *$ & $158.90 * * *$ & $151.37 * * *$ & $68.13 * * *$ \\
\hline Log likelihood & -458.1209 & -383.2939 & -412.4187 & -479.5480 & -182.952 \\
\hline $\mathrm{R}^{2}$ & 0.1226 & 0.1174 & 0.1615 & 0.1363 & 0.1570 \\
\hline
\end{tabular}

Table A. 2. Estimation Results for Probit Models (Coefficient Estimates) 